\title{
Southern Lyctus Beetle, Lyctus planicollis LeConte (Insecta: Coleoptera: Bostrichidae: Lyctinae) ${ }^{1}$
}

Angela S. Brammer ${ }^{2}$

\section{Introduction}

The term "powderpost beetle" is often used to describe two families: Anobiidae (deathwatch beetles) and Bostrichidae (false powderpost beetles). The true powderpost beetles, of the subfamily Lyctinae (formerly family Lyctidae) within the family Bostrichidae, earned their common name from the very fine powdery frass found in their tunnels. Eleven lyctine species have been found in the U.S. Florida has three Lyctus species and one species each in the genera Minthea and Trogoxylon (both subfamily Lyctinae). Of the three Lyctusspecies, one is an introduced seed feeder and another is rarely encountered. Only L. planicollis is common and destructive throughout the South.

Lyctine beetles, also known as lyctid beetles, are second only to termites in their destruction of structural wood. They are serious pests of hardwoods, mainly ash, hickory, oak, maple and mahogany. Lyctines usually infest dry, seasoned wood that is less than five years old. Hardwood-product manufacturers struggle with lyctine infestations. These businesses are concentrated in the South, where the warm, humid climate is favorable to beetle development. Also, lyctine beetles commonly enter the U.S. from the tropics through Southern ports, ending up in lumberyards where the opportunities for reinfestation are great.

\section{Distribution}

Although they also occur in natural conditions, lyctines are closely associated with humans. They travel with people as they move from place to place inside their furniture or other wood products. They can infest wood in one location, be transported with the wood to a new location, and finally emerge thousands of miles away from their origin to reinfest local timber. They are common throughout the U.S. and can be found in just about any wood product, including hardwood flooring, hardwood timbers, plywood, crating, furniture, tool handles, ladders, picture frames and baskets, among others. They are also common in lumberyards. They are found throughout the year in buildings but are most commonly found during warmer months due to their increased activity.

1. This document is EENY-283, one of a series of Featured Creatures from the Entomology and Nematology Department, Florida Cooperative Extension Service, Institute of Food and Agricultural Sciences, University of Florida. Published: March 2003. This document is also available on Featured Creatures Website at http://creatures.ifas.ufl.edu. Please visit the EDIS Website at http://edis.ifas.ufl.edu. 2. Angela S. Brammer, Entomology and Nematology Department, University of Florida, Gainesville.

The Institute of Food and Agricultural Sciences (IFAS) is an Equal Employment Opportunity - Affirmative Action Employer authorized to provide research, educational information and other services only to individuals and institutions that function without regard to race, creed, color, religion, age, disability, sex, sexual orientation, marital status, national origin, political opinions or affiliations. For information on obtaining other extension publications, contact your county Cooperative Extension Service office. Florida Cooperative Extension Service / Institute of Food and Agricultural Sciences / University of Florida / Larry R. Arrington, Interim Dean 


\section{Identification}

Lyctus planicollis varies from 4 to $6 \mathrm{~mm}$ in length. Lyctines in general are very small beetles, ranging from $2 \mathrm{~mm}$ to $7.5 \mathrm{~mm}$ in length. They are generally brown or reddish-brown, although they can sometimes be black. The body is elongated and slightly flattened. The head is prominent and is not covered by the pronotum. The antennae have 11 segments, and the last two segments are broadened into a terminal club. The elytra are striated with double rows of small puncture marks between striations. A sparse, short, yellowish pubescence covers the body. Adult lyctine beetles closely resemble flour beetles, but they can be distinguished by the two-segmented club (flour beetles have a three-segmented club). The tibia feature two distinct spurs. The larvae are yellowish-white, "C-shaped," and about $7.5 \mathrm{~mm}$ long with an enlarged spiracle on the eighth abdominal segment. Eggs are translucent, about $1 \mathrm{~mm}$ long and cylindrical with rounded ends. They usually cannot be seen because the female lays them deep within the pores of the wood.

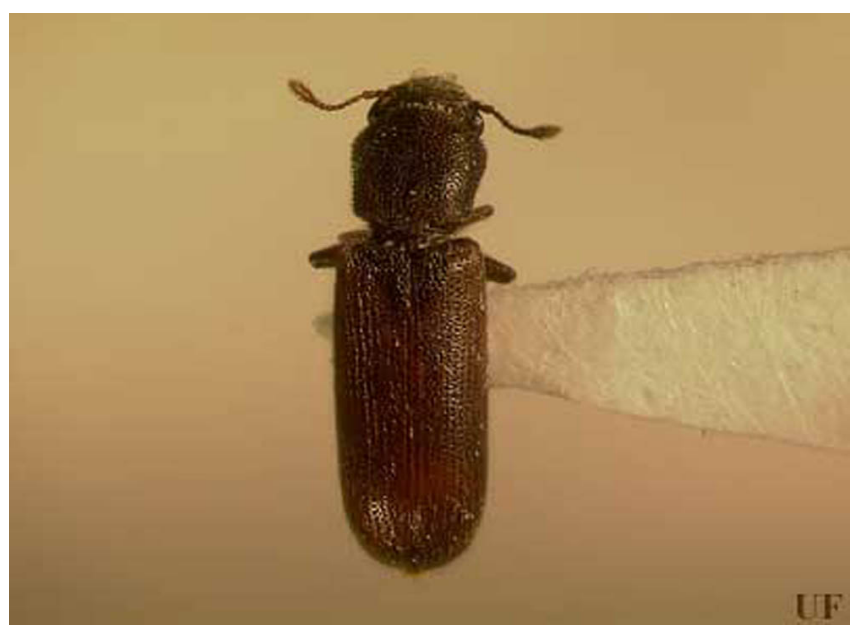

Figure 1. The appearance of this Lyctus beetle is typical of true powderpost beetles. Lyctines are very small beetles, ranging from $2 \mathrm{~mm}$ to $7.5 \mathrm{~mm}$ in length. They are generally brown or reddish-brown, as this one is, although they can sometimes be black. The body is elongated and slightly flattened. The head is prominent and is not covered by the pronotum. Credits: Angela S. Brammer, University of Florida

The most obvious and often the only sign of infestation is the presence of exit holes. Adults leave behind circular holes of about 0.8 to $1.5 \mathrm{~mm}$ in

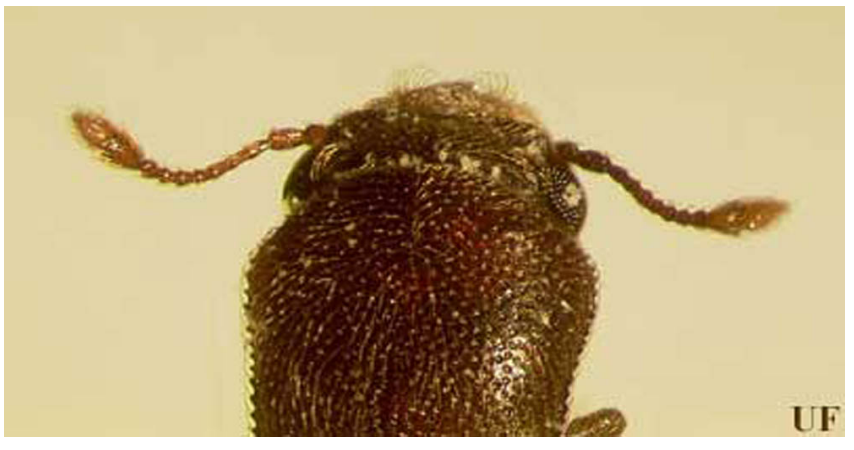

Figure 2. This Lyctus beetle's head is prominent and is not covered by the pronotum, a characteristic of the subfamily Lyctinae (family Bostrichidae). The antennae have 11 segments, and the last two segments are broadened into a terminal club. Adult lyctine beetles closely resemble flour beetles, but they can be distinguished by the two-segmented club (flour beetles have a three-segmented club). Credits: Angela S. Brammer, University of Florida

diameter when they emerge from the wood, which occurs most commonly from April to July.

\section{Life Cycle and Biology}

Lyctus planicollis, like other lyctine beetles, undergoes complete metamorphosis. It hibernates as a larva, pupates in the spring, and emerges as an adult in the early summer. Typically, the entire life cycle takes about a year, but it can vary from six months up to four years under adverse conditions. In heated buildings, development can occur more quickly. The larval stage is the one responsible for most of the damage, and the length of this stage accounts for the variability in the length of the life cycle.

Adult lyctines mate soon after emerging from the wood. The female then begins laying eggs in pores on the surface of a piece of wood (either the one she has emerged from or another suitable one). Egg laying continues for about a week. Powderpost beetles only lay eggs on bare, unfinished wood. They will oviposit in small cracks and crevices in the wood as well as in the pores on the surface. Recent emergence holes are common sites of oviposition. An average female lays bout 15 to 50 eggs during this time.

Depending on temperature, eggs can take one to three weeks to hatch. The young larvae bore deeper into the wood through the bottom of the pore in which they hatched. Larvae tend to feed along the grain of the wood, but in later instars, they will cross 


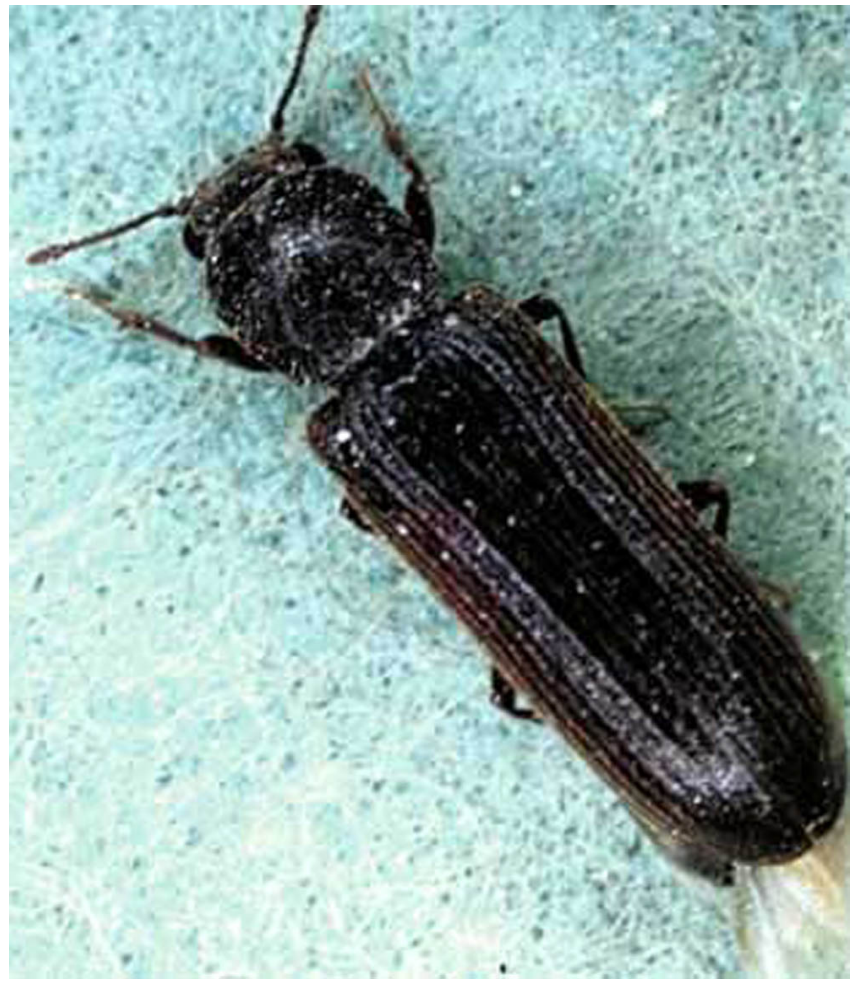

Figure 3. Southern lyctus beetle, Lyctus planicollis LeConte, adult female. Typically, adults are 2 to $7.5 \mathrm{~mm}$ long. Credits: USDA Forest Service - Wood Products Insect Lab Archives, USDA Forest Service, www.forestryimages.org

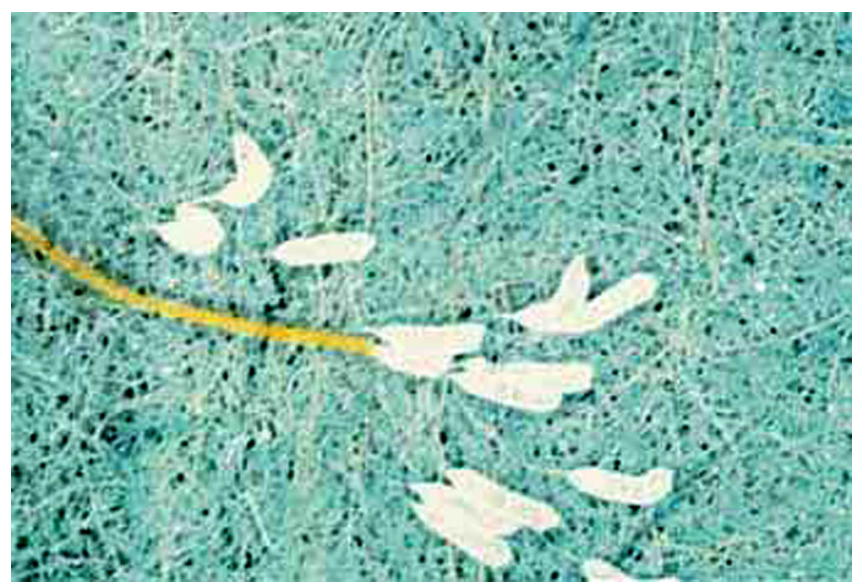

Figure 4. Southern lyctus beetle, Lyctus planicollis LeConte, eggs. Eggs are usually $1 \mathrm{~mm}$ long and translucent or white. Credits: USDA Forest Service - Wood Products Insect Lab Archives, USDA Forest Service, www.forestryimages.org

the grain. As they feed, they fill the tunnels with the powderlike frass that gives them their common name. Just like drywood termites, the larvae may tunnel all the way to the surface of the wood, eating away most of the material there, but they will not break the surface. Because of this behavior, heavily infested wood has a paperlike outer layer that is easily broken. Generally, the larvae confine their feeding to the sapwood. Thanks to indoor heating, they can develop in all seasons, but normally, most activity occurs in the spring and summer. When it is ready to pupate, a larva bores close to the surface and builds a pupal chamber. The pupal stage can last anywhere from 12 days to a month under normal conditions. The new adult chews its way to the surface and emerges, leaving behind a 0.8 to $1.5 \mathrm{~mm}$ circular hole. Adult lyctines are nocturnal. They hide in cracks and crevices during the day. At night, they will fly to lights. Most adults live one to three months.

Lyctines can live in wood with a moisture content of about 6 to 30 percent, but the greatest activity occurs between 10 and 20 percent. Starch content needs to be 3 percent or higher to make an attractive oviposition site for a lyctine beetle. Powderpost beetles feed on the starchy content of the wood; they do not digest cellulose or lignin because they cannot produce cellulases. Because of this, their activity is restricted to sapwood.

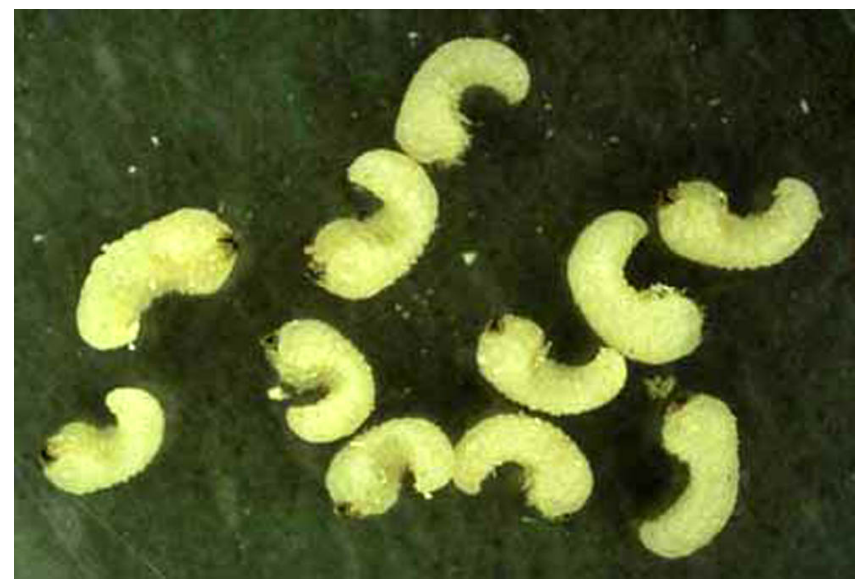

Figure 5. Larvae of southern lyctus beetle, Lyctus planicollis LeConte. Credits: USDA Forest Service - Wood Products Insect Lab Archives, USDA Forest Service, www.forestryimages.org

\section{Damage}

Lyctines prefer new wood, only rarely infesting wood more than five years old. They also attack bamboo. The most common infestations are found in new homes or newly manufactured wood products. In most cases, the wood was already infested with eggs or larvae at the time of purchase because it was not stored or dried properly. 


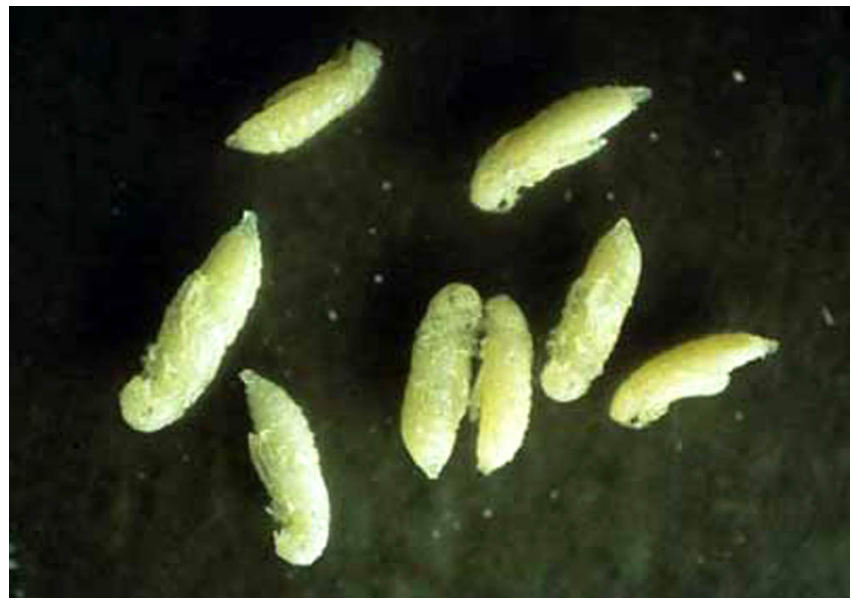

Figure 6. Pupae of southern lyctus beetle, Lyctus planicollis LeConte. Credits: USDA Forest Service - Wood Products Insect Lab Archives, USDA Forest Service, www.forestryimages.org

Most infestations are found in wood paneling, door and window frames, hardwood floors and furniture. Subfloors, joists and rafters often escape infestation because they are usually made of pine or other softwoods. Because of poor storage and drying practices prior to shipment, imported tropical hardwoods are sometimes heavily infested with lyctines.

External signs of damage are often not readily apparent until the adults emerge. When adults emerge, they leave behind emergence holes about 0.8 to 1.5 $\mathrm{mm}$ wide. Any slight movement will cause powdery frass to cascade from the emergence holes, collecting below the infested wood in little piles that homeowners sometimes mistake for sawdust. The diameter of the frass piles is proportional to the height of the holes. If an infested piece of wood is cut open, the interior may contain a large amount of loosely packed frass. Occasionally, so much frass can collect that it may burst the papery skin of the wood. When rubbed between the fingers, lyctine frass feels like talc or flour.

The presence of emergence holes does not necessarily signify an active infestation. Sometimes an infestation will die out on its own over time. Dealing with lyctine damage can often be confusing and frustrating to property owners who get conflicting reports from different sources about whether the infestation is active or not. Powderpost beetles damage wood relatively slowly. Take the time

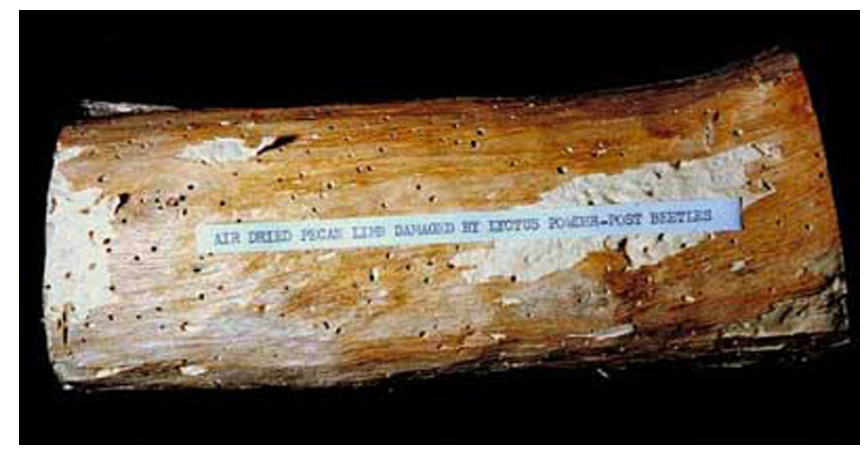

Figure 7. The small emergence holes typical of a lyctine beetle infestation can be seen in this pecan limb. Credits: USDA Forest Service - Wood Products Insect Lab Archives, USDA Forest Service, www.forestryimages.org

necessary to weigh all factors involved before deciding on the most appropriate course of action.

\section{Management}

Several options exist for handling infestations of L. planicollis and other lyctines. The right choice for a given situation depends on the severity of the infestation, the location of the infestation, the potential for reinfestation, and cost.

Wood varnishes will prevent lyctines from laying their eggs in the pores on the surface of the wood. Beetles found in wood that has been varnished, sealed, painted or waxed were either present in the wood before it was finished or they were able to lay their eggs in the holes left by emerging adult beetles. Sealing any holes in new hardwoods will prevent reinfestation.

Another option is replacing the infested wood. If it can be determined that the infestation is confined to a single piece of wood such as a windowsill, as is often the case, remove the infested piece and replace it with uninfested wood.

Very small articles can be placed in a freezer to kill the adults and larvae. A sustained temperature of $0^{\circ} \mathrm{F}$ for at least 72 hours is required for this method to be effective. Eggs are very tolerant of cold, and this method may not be entirely effective as a result.

Chemical treatments come in two kinds: surface and fumigation. Fumigation is considered to be the most effective method of lyctine control, but it is also the most costly. If the infestation is widespread, the entire structure may have to be tented and fumigated. 
Pest control operators can often fumigate furniture or small items such as picture frames or wicker baskets inside a small chamber designed for that purpose. A drawback of fumigation is that it does not provide residual protection of the wood. If a second infestation in a nearby article goes undetected, lyctine beetles can easily reinfest the fumigated item once it is returned to the structure. Surface treatments can be applied to bare, exposed wood by certified pesticide applicators. These insecticides work in two ways. First, they form a toxic barrier on the surface of the wood that kills adults trying to emerge or newly-hatched larvae attempting to bore into the wood. Second, in some cases, the insecticide can penetrate the wood deeply enough to kill larvae inside, preventing the appearance of additional emergence holes. Surface treatments generally take a long time, possibly years depending on the life cycle of the species, to be completely effective.

The optimal way to control a structural lyctine beetle infestation would be to prevent the insects from entering the structure in the first place. Although it may not always be possible to detect an early infestation by visual inspection, some infestations will be readily apparent in new wood. Carefully inspect any new hardwood products, including those used in new home construction, before incorporating them into the structure.

For more detailed information, including pesticide labeling, please consult the Insect Management Guide for Powderpost Beetles (http://edis.ifas.ufl.edu/IG119).

\section{Selected References}

Bennett GW. (July 2001). Powderpost beetles. Purdue University Cooperative Extension Service, E-73. http://www.entm.purdue.edu/Entomology/ext/ targets/e-series/EseriesPDF/E-73.pdf (18 December 2002).

DeAngelis J. (July 1995). Preventing and controlling powderpost beetles in and around the home. Pacific Northwest Extension, Oregon State University, PNW 326. http://eesc.orst.edu/ agcomwebfile/edmat/html/pnw/pnw326/pnw326.html (18 December 2002).
Dillon ES, Dillon LS. 1972. A Manual of Common Beetles of Eastern North America, Volume 2. New York: Dover Publications, 894 pp.

Ebeling W. 1975. Urban Entomology. Berkeley: University of California Press, 695 pp.

Hickin NJ. 1972. The Woodworm Problem. London: Hutchinson Benham Ltd., 123 pp.

Ivie MA. 2002. Bostrichidae. In American Beetles; Arnett RH Jr, Thomas MC, Skelley PE, Frank JH (eds.) Boca Raton: CRC Press.

Koehler PG. (May 1999). Powderpost beetles and other wood-destroying insects. Florida Cooperative Extension Service, Institute of Food and Agricultural Sciences, University of Florida, ENY-266. http://edis.ifas.ufl.edu/IG119 (18 December 2002).

Merchant M. (September 2001). Lyctid powderpost beetles: Suggestions for control. House \& Landscape Pest Series, Department of Entomology, Texas A\&M University, Ent-1022. http://dallas. tamu.edu/insects/Ent-1022.html (18 December 2002).

Papp CS. 1984. Introduction to North American Beetles. Sacramento, Calif.: Entomography Publications, 335 pp.

Rust MK, Paine EO, and Reierson DA. 1997. Evaluation of Freezing to Control Wood-Destroying Insects (Isoptera, Coleoptera). Journal of Economic Entomology 90: 1215-1221.

White RE. 1983. A Field Guide to the Beetles of North America. Boston: Houghton Mifflin. 368 pp.

Williams LH. 1985. Integrated protection against lyctid beetle infestations. U.S. Dept. of Agriculture, Forest Service, Forest Experiment Station. 12 pp.

Wilson SE. 1932. Powderpost beetles. Nature 130: 22-23. 